\title{
Key Mutations in the Cylindrical Inclusion Involved in Lettuce mosaic virus Adaptation to elF4E-Mediated Resistance in Lettuce
}

\author{
M. Sorel, ${ }^{1,2}$ L. Svanella-Dumas, ${ }^{1,2}$ T. Candresse, ${ }^{1,2}$ G. Acelin,, ${ }^{1,2}$ A. Pitarch, ${ }^{1,2}$ M. C. Houvenaghel, ${ }^{1,2}$ and \\ S. German-Retana ${ }^{1,2}$ \\ ${ }^{1}$ INRA and ${ }^{2}$ Université de Bordeaux, UMR BFP 1332, Equipe de Virologie, CS 20032, 33882 Villenave d'Ornon, France \\ Submitted 15 April 2014. Accepted 12 May 2014.
}

\begin{abstract}
We previously showed that allelic genes $\mathrm{mol}^{1}$ and $\mathrm{mol}^{2}$ used to protect lettuce crops against Lettuce mosaic virus (LMV) correspond to mutant alleles of the gene encoding the eukaryotic translation initiation factor $4 \mathrm{E}$. LMV resistance-breaking determinants map not only to the main potyvirus virulence determinant, a genome-linked viral protein, but also to the $\mathrm{C}$-terminal region of the cylindrical inclusion (CI), with a key role of amino acid at position 621. Here, we show that the propagation of several non-lettuce isolates of $\mathrm{LMV}$ in $\mathrm{mol}^{1}$ plants is accompanied by a gain of virulence correlated with the presence in the $\mathrm{CI} C$ terminus of a serine at position 617 and the accumulation of mutations at positions 602 or 627. Whole-genome sequencing of native and evolved isolates showed that no other mutation could be associated with adaptation to mo1 resistance. Site-directed mutagenesis pinpointed the key role in the virulence of the combination of mutations at positions 602 and 617 , in addition to position 621 . The impact of these mutations on the fitness of the virus was evaluated, suggesting that the durability of $\mathrm{mol}$ resistance in the field relies on the fitness cost associated with the resistance-breaking mutations, the nature of the mutations, and their potential antagonistic effects.
\end{abstract}

The genus Potyvirus is considered to be one of the largest among plant viruses, causing considerable economic losses in various crops (Adams et al. 2011). Potyviruses have nonenveloped flexuous filamentous particles, encapsidating a positive single-stranded RNA, covalently linked at its $5^{\prime}$ end to a genome-linked viral protein $(\mathrm{VPg})$ and polyadenylated at its $3^{\prime}$ end. This RNA encodes a large polyprotein processed by three virus-encoded proteases into 10 multifunctional proteins. In addition, a frameshifted open reading frame encoding a small protein, P3N-PIPO, has been identified (Chung et al. 2008).

\section{Sorel and L. Svanella-Dumas contributed equally to this work}

Current address for A. Pitarch: UMR CNRS 8626, Université Paris-Sud, F-91405 Orsay, France.

Corresponding author: S. German-Retana;

E-mail: german@bordeaux.inra.fr

* The $\boldsymbol{e}$-Xtra logo stands for "electronic extra" and indicates that five supplementary tables and one supplementary figure are published online.

(C) 2014 The American Phytopathological Society
Control of plant viruses in the field relies, in part, on the deployment of genetic resistances (Kang et al. 2005). Unlike for other plant pathogens, recessive resistances are the most common against plant viruses (Diaz-Pendon et al. 2004; Kang et al. 2005). Such resistance is likely to be passive, being the consequence of the loss (null allele) or mutation of a host factor required by the virus to complete a particular step of its infectious cycle (Fraser 1992). In recent years, components of the eukaryotic translation initiation complex such as eukaryotic translation initiation factor eIF4E and, to a lesser extent, eIF4G, have been identified as essential determinants in the outcome of potyviral infection (Nicaise et al. 2007; Wang and Krishnaswamy 2012). In particular, recessive allelic lettuce genes $\mathrm{mol}^{1}$ and $\mathrm{mol}^{2}$, currently used worldwide to protect lettuce crops against Lettuce mosaic virus (LMV), have been shown to correspond to mutant alleles of the gene encoding the translation initiation factor eIF4E (German-Retana et al. 2008a; Nicaise et al. 2003). LMV, a member of the genus Potyvirus, is a major pathogen of worldwide distribution in commercial lettuce crops (Dinant and Lot 1992). Like other potyviruses, it is transmitted by aphids in a nonpersistent manner, while some LMV isolates are also seedborne in lettuce (Dinant and Lot 1992). A range of species within the family Asteraceae are susceptible to LMV, including cultivated and ornamental species such as common (Lactuca sativa) or wild (L. virosa) lettuce, Cape daisy (Dimorphoteca or Osteospermum spp.), and Gazania (Gazania rigens). In addition, a few species within the families Brassicaceae, Cucurbitaceae, Fabaceae, Solanaceae, and Chenopodiaceae are natural or experimental hosts of LMV (Dinant and Lot 1992; German-Retana et al. 2008b), including Nicotiana benthamiana and Arabidopsis thaliana.

Depending on the LMV isolate to which they are confronted, the mol genes can confer true resistance (no detectable virus systemic accumulation) or tolerance (virus accumulation in the absence of symptoms). Even though the mechanism underlying eIF4E-mediated resistance is still unknown, it has been demonstrated that the $m o l^{2}$ allele partially inhibits the intercellular movement of the avirulent LMV-0 isolate and affects its phloem loading and unloading (German-Retana et al. 2003).

Attempts to link the biological properties of LMV isolates with their phylogeny have been carried out (Krause-Sakate et al. 2002; Revers et al. 1997). LMV isolates sampled in lettuce could be clustered in three main groups: a single isolate from Yemen, a group from the Balkans (Greece and Croatia, named $\mathrm{Gr}$ ), and a third group with very diverse geographical origins (called "Rest of the World" [RoW]) (German-Retana et al. 2008b). Within the RoW group, two large subclusters of iso- 
lates contained all known seedborne LMV isolates: one with isolates unable to infect $\mathrm{mol}^{1}$ or $\mathrm{mol}^{2}$ plants, collectively named "LMV-Common", and the other with the isolates cumulating mol-breaking and seed transmission properties, collectively named "LMV mol-breaking, seed-transmitted" (LMVMost).

Although the mol resistance has largely remained effective since its intensive deployment, occasional outbreaks of LMV in resistant lettuce have been reported and may represent a threat to resistance durability (Krause-Sakate et al. 2002). Our previous work demonstrated that the VPg from a virulent isolate (LMV-E) enabled the multiplication of an avirulent isolate (LMV-0, group Common) in $\mathrm{mol}^{1}$ - but not in $\mathrm{mol}^{2}$-resistant plants, while the C-terminal region of the LMV-E cylindrical inclusion $(\mathrm{CI})$ helicase carried determinants for both $\mathrm{mol}^{l}$ and $\mathrm{mol}^{2}$ resistance breaking (Abdul-Razzak et al. 2009). Therefore, LMV shows a complex picture, with two genomic regions independently conferring the ability to overcome eIF4E-mediated resistance in lettuce and providing the first example of a potyviral CI acting as an eIF4E resistance-breaking determinant (Abdul-Razzak et al. 2009). In particular, the S621T mutation in the CI C terminus (CI-Cter) was demonstrated to confer $\mathrm{mol}^{1}$ and $\mathrm{mol}^{2}$ resistance-breaking properties to LMV-0 (Abdul-Razzak et al. 2009).

There are many examples of damaging viruses moving into cultivated crops from native ecosystems, and it has been argued that "the viral genetic variability contained in reservoir populations is the most important genetic determinant of viral emergence" (Elena et al. 2011). It is generally assumed that weeds and wild hosts have a broader genetic diversity than crop species and, therefore, harbor viral populations with a higher genetic diversity, potentially including resistance-breaking variants (Chiba et al. 2010).

Weeds and ornamental plants could act as LMV local reservoirs for lettuce crops (Zerbini et al. 1995). Whether this may contribute to the breakdown of the mol resistance deployed in lettuce crops is still unknown. The first objective of the present study was to evaluate the biological behavior of non-lettuce isolates (weeds and ornamental isolates) of LMV in resistant and susceptible cultivated lettuce genotypes. The results obtained show that propagation of five non-lettuce isolates of LMV in $\mathrm{mol}^{1}$ lettuce was accompanied by a gain of virulence correlated with the accumulation of mutations in the CI-Cter, when the same isolates propagated in susceptible lettuce did not accumulate mutations and did not show a gain in virulence. The $\mathrm{mol}^{1}$-evolved isolates had simultaneously gained the ability to overcome the $\mathrm{mol}^{2}$ resistance. Whole-genome sequencing of native and evolved isolates determined that no other mutation could be associated with adaptation to the mol resistance. Sitedirected mutagenesis of an infectious clone of the avirulent LMV-0 isolate demonstrated the cumulative contribution of mutations in the CI-Cter to resistance breaking. Finally, an analysis of the competitiveness of the various LMV-0-derived point mutants demonstrated that only one single mutant is counterselected in susceptible crops, whereas no clear fitness cost can be associated with the other mutations tested.

\section{RESULTS}

Acquisition of specific mutations in the C-terminal region of the CI allows non-lettuce LMV isolates to adapt to mo1 resistance in lettuce.

A study focused on the molecular and biological diversity of LMV isolates originating from various hosts has identified wild or ornamental host-specific and geographically limited clusters with the large RoW cluster (T. Candresse, L. SvanellaDumas, H. Fakhfakh, M. Rosales-Villavicencio, R. KrauseSakate, M. Zerbini, C. Varveri, and O. Le Gall, unpublished data). We chose the five isolates (Supplementary Table S1) as representatives of the LMV clusters originating from wild lettuce or from the widely cultivated Cape daisy (Dimorphoteca spp.). They were propagated from their original host onto sus-

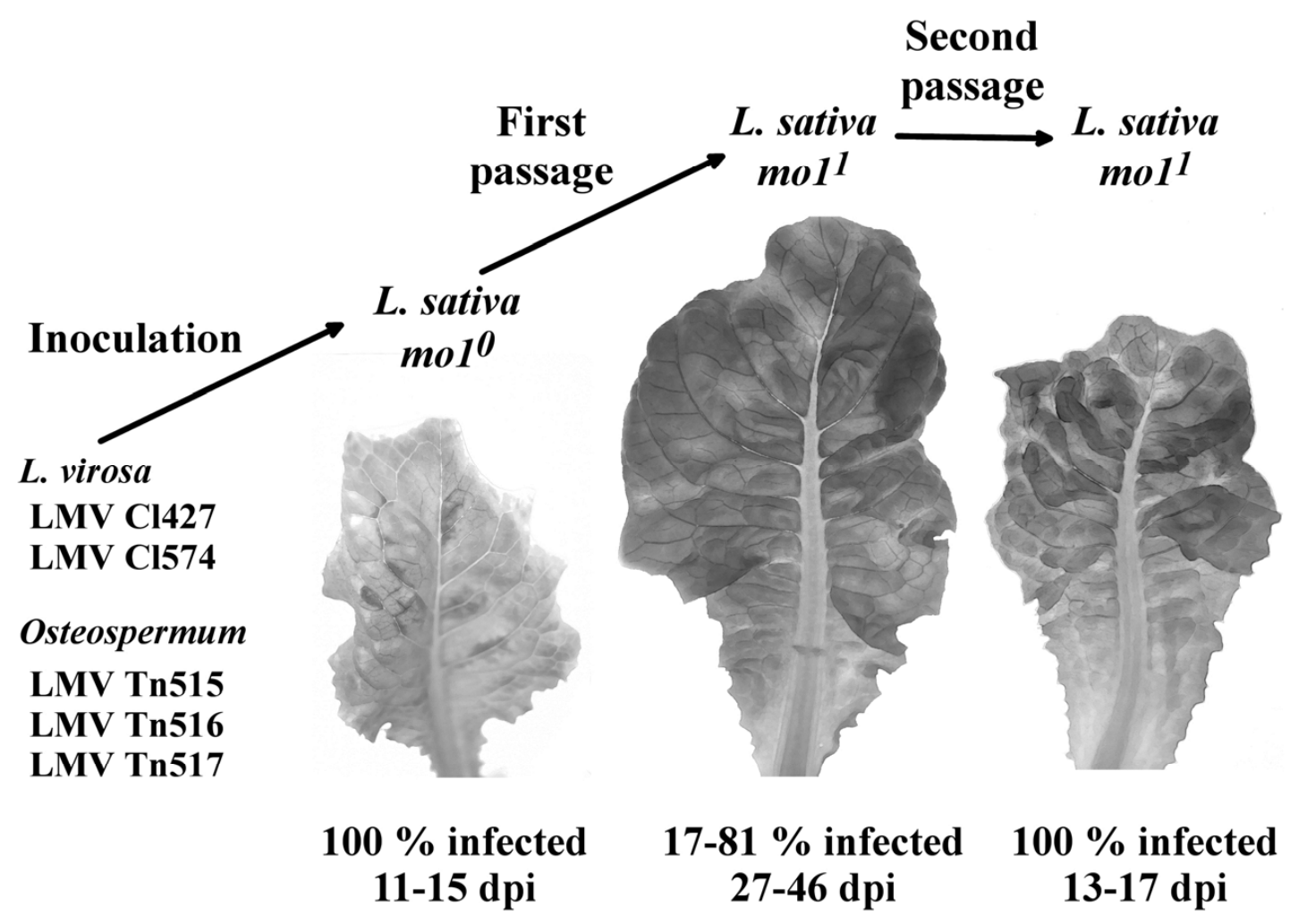

Fig. 1. Evolution toward resistance-breaking of non-lettuce Lettuce mosaic virus isolates following inoculation of $m o 1^{1}$-resistant lettuce plants. 
ceptible $\mathrm{mol}^{0}$ lettuce 'Trocadéro' using mechanical inoculation, as described below. All inoculated plants displayed mosaic symptoms on the upper noninoculated leaves as early as 11 days postinoculation (dpi). The five isolates were then inoculated onto resistant $\mathrm{mol}^{1}$ lettuce 'Mantilia'. This was accompanied by the appearance of a few chlorotic spots on some plants, before appearance of a systemic mosaic at 27 to $46 \mathrm{dpi}$ (Fig. 1). Therefore, the symptoms appeared much later than in susceptible Trocadéro lettuce and only in some of the inoculated resistant plants, suggesting a potential gain of virulence of non-lettuce LMV isolates in $\mathrm{mol}^{l}$ lettuce.

In order to better characterize this potential propensity to evolve toward virulence, efforts were then focused on three isolates: Cl574, Tn515, and Tn517. Each isolate infected $100 \%$ of susceptible lettuce plants (Table 1) but the rate of $m o l^{1}$-resistant Mantilia plants ultimately developing mosaic symptoms varied from $81 \%(\mathrm{Cl} 574)$ to 17 and $22 \%$ for $\mathrm{Tn} 517$ and Tn515, respectively (Table 1). No symptoms were observed, even long after inoculation, in $\mathrm{mol}^{2}$-resistant lettuce of the $8714132 \mathrm{M}$ line, and the absence of viral accumulation was confirmed by reverse-transcription polymerase chain reaction (RT-PCR). However, in one experiment, the inoculation of isolates $\mathrm{Cl} 574$ and $\mathrm{Tn} 515$ was carried out with the $m o l^{2}$-resistant lettuce 'Salinas 88 ' and resulted in the development of symptoms appearing 30 to $60 \mathrm{dpi}$ in some of the inoculated plants (Table 1). This was not tested for isolate Tn517.

The viral isolates present in the $m o l^{l}$ symptomatic plants were then inoculated onto $\mathrm{mol}^{0}, \mathrm{~mol}^{l}$, and $\mathrm{mol}^{2}$ plants. Whatever their resistance genotype, $100 \%$ of plants were infected (Table 1), with severe symptoms appearing in $\mathrm{mol}^{1}$ and $m o l^{2}$ plants much more rapidly (from 13 to $17 \mathrm{dpi}$ ) (Fig. 1). Therefore, $m o l^{l}$ resistance-breaking variants have been selected during the first passage on $\mathrm{mol}^{1}$-resistant plants, and they are able to overcome not only $\mathrm{mol}^{l}$ but also $\mathrm{mol}^{2}$ resistance.

The sequence of the viral isolate present in $\mathrm{mol}^{1}$ Mantilia plants ultimately developing symptoms following the initial inoculation experiments was then analyzed to identify potential mutations associated with the gain of virulence. Initial efforts targeted the CI-Cter to VPg genomic region associated with resistance breaking (Abdul-Razzak et al. 2009). In two independent experiments, mutations could be detected after the first propagation in $\mathrm{mol}^{l}$ at two positions in the CI-Cter sequence, depending on the isolate (Table 2). These mutations were a substitution of an alanine by a valine at position 602 (A602V) for $\mathrm{Cl} 574$ and $\mathrm{Tn} 515$ (in each case in three-quarters of the sequenced progenies) and a substitution of an alanine by a threonine at position 627 (A627T) for both Tn515 and Tn517 in one-quarter and one-third, respectively, of the sequenced progenies. Despite the presence of symptoms in the analyzed $m o 1^{1}$ lettuce plants, for each isolate, in at least one or two of the analyzed progenies, no mutation could be detected through RT-PCR sequencing of the CI-Cter to VPg region (Table 2), the resistance-breaking variants being probably underrepresented in the viral progenies, with the absence of visible dual peaks in the electrophoregrams (data not shown). The A602V mutation was also detected after propagation of the $\mathrm{Cl} 574$ and Tn515 isolates in $\mathrm{mol}^{2}$ lettuce whereas no mutation was detected after propagation of any of these non-lettuce LMV isolates in susceptible lettuce (Table 2).

For the variants selected on $\mathrm{mol}^{1}$ and retro-inoculated on $m o l^{1}$ or $m o l^{2}$ plants, previously identified mutations were detected in $100 \%$ of the sequenced progenies, revealing the stability of the mutations (Table 3). Furthermore, additional mutations not detected in the inoculum were also detected in some cases after the second passage on resistant plants, again affecting amino acids at position 602 or 627 (Table 3). Overall, depending on the LMV isolate, different patterns of accumulation of mutations in the CI-Cter to VPg region can be observed. The simplest situation is that of $\mathrm{Cl} 574$, for which the A602V mutation is the only one observed. This mutation was observed to be fixed in the progenies analyzed following a second passage in resistant plants. In the case of the Tn515 isolate, the same was observed for the A602V mutation but it was accompanied in some propagation lineages by the A627T mutation. Finally, the Tn517 isolate represents the most complex situation because, depending on the propagation lineage, each

Table 1. Proportion of infected plants of the susceptible $\left(\mathrm{mol}^{0}\right)$ or resistant $\left(\mathrm{mol}^{1}\right.$ and $\left.m o l^{2}\right)$ lettuce varieties following inoculation with non-lettuce Lettuce mosaic virus isolates $\mathrm{C} 1574, \mathrm{Tn} 515$, and $\mathrm{Tn} 517^{\mathrm{a}}$

\begin{tabular}{|c|c|c|c|c|c|c|}
\hline \multirow[b]{2}{*}{ Isolate } & \multicolumn{3}{|c|}{ First passage: $\mathrm{mol}^{0}$ inoculum } & \multicolumn{3}{|c|}{ Second passage : $\mathrm{mol}^{1}$ inoculum } \\
\hline & $m o 1^{0}(11 \mathrm{dpi})$ & $m o 1^{1}(60 \mathrm{dpi})$ & $m o 1^{2}(60 \mathrm{dpi})$ & $m o 1^{0}(11 \mathrm{dpi})$ & $m o 1^{1}(13 \mathrm{dpi})$ & $\operatorname{mol}^{2}(17 \mathrm{dpi})$ \\
\hline $\mathrm{C} 1574$ & $8 / 8$ & $17 / 21$ & $2 / 5^{*}$ & $10 / 10(3)$ & $22 / 22(2)$ & $9 / 9(2)$ \\
\hline $\operatorname{Tn} 515$ & $8 / 8$ & $4 / 18$ & $3 / 7 *$ & $8 / 8(4)$ & $21 / 21(4)$ & $15 / 15(3)$ \\
\hline Tn517 & $8 / 8$ & $3 / 18$ & nd & $16 / 16(5)$ & $26 / 26(4)$ & $13 / 13(3)$ \\
\hline
\end{tabular}

${ }^{\text {a }}$ The inoculum used had been propagated on $\mathrm{mol}^{0}$-susceptible lettuce (first passage: $\mathrm{mol}^{0}$ inoculum) or propagated a first time on resistant $\mathrm{mol}^{l}$ plants (second passage: $\mathrm{mol}^{1}$ inoculum). For the first passage, at least two independent experiments were performed and the composite results are shown, except in one experiment ( $\mathrm{mol}^{2}$ 'Salinas $88^{\prime}$ ' plants), indicated by *. The number of independent plants used as sources of inoculum for the second passage is given in parentheses. The date of appearance of the symptoms at days postinoculation (dpi) is indicated; nd = not determined.

Table 2. Mutations observed in the cylindrical inclusion $\mathrm{C}$ terminus to genome-linked viral protein (CI-Cter to VPg) region of the viral progeny of nonlettuce Lettuce mosaic virus isolates, after their passaging in $m o 1^{0}, m o 1^{1}$, or $m o 1^{2}$ lettuce cultivars ${ }^{\mathrm{a}}$

\begin{tabular}{|c|c|c|c|c|c|}
\hline \multirow[b]{2}{*}{ Isolate } & $\mathrm{mol}^{0}$ (susceptible) & \multicolumn{2}{|c|}{$\operatorname{mol}^{1}($ resistant $)$} & \multicolumn{2}{|c|}{ mol $^{2}$ (resistant) } \\
\hline & A627 & A602 & A627 & A602 & A627 \\
\hline $\mathrm{Cl} 574$ & No mutation $(5 / 5)$ & $\overline{\mathrm{V}}$ & $\begin{array}{l}-(1 / 4) \\
-(3 / 4)\end{array}$ & V & $-(2 / 2)^{*}$ \\
\hline Tn515 & No mutation $(5 / 5)$ & $\begin{array}{l}- \\
\text { V } \\
\text { V }\end{array}$ & $\begin{array}{l}-(1 / 4) \\
-(2 / 4) \\
\mathrm{T}(1 / 4)\end{array}$ & V & $-(3 / 3)^{*}$ \\
\hline Tn517 & No mutation (4/4) & - & $\begin{array}{l}-(2 / 3) \\
\mathrm{T}(1 / 3)\end{array}$ & nd & nd \\
\hline
\end{tabular}

\footnotetext{
${ }^{a}$ The number of plants for which the sequenced progeny showed a particular haplotype and the total number of plants from which the progeny was characterized are indicated in parentheses. $\mathrm{V}=$ valine, $\mathrm{T}=$ threonine, and - indicates no mutation. Results shown are derived from at least two independent inoculation experiments except in one experiment $(*)$; nd $=$ not determined.
} 
of these two mutations could be observed alone or in combination (Table 3).

Sequencing of the RT-PCR-amplified CI-Cter to VPg coding region of the variants after their propagation in $\mathrm{mol}^{\circ}$ lettuce shows that mutations acquired during the first passage on $m o l^{l}$-resistant plants are systematically retained (Table 3). Therefore, in the absence of selection pressure driven by the mol allele, no reversion occurred. However, in a few cases, some variants displayed additional mutations not detected after their first passage on $\mathrm{mol}^{l}$ plants (Table 3). Indeed, one Tn515-derived variant was observed with an additional A627T mutation while three Tn517-derived variants were selected with an additional A602V mutation. As mentioned above, it is probable that those mutations were already present but underrepresented in the parental population.

The $m o l^{2}$-resistance-breaking variants derived from $\mathrm{Cl} 574$ and Tn515 after a first passage on $\mathrm{mol}^{2}$ Salinas 88 (Table 1) were retro-inoculated on both $\mathrm{mol}^{2}$ and susceptible lettuce, and $100 \%$ of $\mathrm{mol}^{2}$ plants displayed symptoms of mosaic as soon as $12 \mathrm{dpi}$. Therefore, similarly to the $\mathrm{mol}^{\mathrm{l}}$-evolved isolates, the variants that emerged in $m o l^{2}$ plants by acquiring the A602V mutation are stable during a second passage in $\mathrm{mol}^{2}$ and do not revert in $\mathrm{mol}^{\circ}$ plants (data not shown).
Full genome sequencing fails

to identify additional mutations consistently

associated with resistance breaking.

The complete genomic sequences of isolates C1427, C1574, Tn515, Tn516, and Tn517 before and after their evolution toward $\mathrm{mol}^{l}$ resistance-breaking were determined using the Illumina deep-sequencing strategy described below.

In addition to the two coding mutations previously identified at positions 602 and 627 in the CI-Cter region, a total of $12 \mathrm{nu}-$ cleotide changes were detected in one or the other of the complete sequences of the five evolved isolates compared with their parental sequences (Table 4). Although seven of those mutations are silent, five of them introduce changes in the predicted amino-acid sequence of the P1, CI, or NIb proteins (Table 4). In order to determine whether these mutations were systematically associated with virulence gain, further targeted sequencing of each of the identified genomic regions was performed on several independently evolved variants derived from each isolate. For isolate $\mathrm{Cl} 574$, the viral progenies from nine $\mathrm{mol}^{l}$ plants displaying symptoms (in addition to those listed in Table 1) and from three $\mathrm{mol}^{\circ}$ plants, were sequenced, whereas at least two independent viral progenies from $\mathrm{mol}^{l}$ plants displaying symptoms were checked for the other four non-lettuce isolates.

Table 3. Mutations observed in the cylindrical inclusion C terminus to genome-linked viral protein (CI-Cter to VPg) region of non-lettuce Lettuce mosaic virus variants selected on $m o l^{1}$-resistant lettuce and of their progeny following passaging in $m o 1^{0}, m o l^{1}$, and $m o l^{2}$ lettuce cultivars ${ }^{\mathrm{a}}$

\begin{tabular}{|c|c|c|c|c|c|c|c|c|c|c|c|c|}
\hline \multirow[b]{3}{*}{ Isolate } & \multicolumn{4}{|c|}{ From $\mathrm{mol}^{1}$ to $\mathrm{mol}^{0}$} & \multicolumn{4}{|c|}{ From $\mathrm{mol}^{1}$ to $\mathrm{mol}^{1}$} & \multicolumn{4}{|c|}{ From $\mathrm{mol}^{1}$ to $\mathrm{mol}^{2}$} \\
\hline & \multicolumn{2}{|c|}{ Inoculum $\mathrm{mol}^{1}$} & \multicolumn{2}{|c|}{ Progeny $\mathrm{mol}^{0}$} & \multicolumn{2}{|c|}{ Inoculum $\mathrm{moI}^{1}$} & \multicolumn{2}{|c|}{ Progeny $\mathrm{mol}^{1}$} & \multicolumn{2}{|c|}{ Inoculum $\mathrm{mol}^{I}$} & \multicolumn{2}{|c|}{ Progeny $\mathrm{mol}^{2}$} \\
\hline & A602 & A627 & A602 & A627 & A602 & A627 & A602 & A627 & A602 & A627 & A602 & A627 \\
\hline \multirow[t]{2}{*}{$\mathrm{Cl574}$} & $\mathrm{V}^{\mathrm{b}}$ & - & $\mathrm{V}$ & $-(5 / 5)$ & $-^{\mathrm{c}}$ & - & $\mathrm{V}$ & $-(3 / 3)$ & $\mathrm{V}^{\mathrm{d}}$ & - & $\mathrm{V}$ & $-(6 / 6)$ \\
\hline & & & & & $\mathrm{V}^{\mathrm{c}}$ & - & $\mathrm{V}$ & $-(3 / 3)$ & & & & \\
\hline \multirow[t]{3}{*}{ Tn515 } & $\mathrm{V}^{\mathrm{d}}$ & - & $\mathrm{V}$ & $-(2 / 3)$ & $-^{\mathrm{c}}$ & - & V & $\mathrm{T}(3 / 3)$ & $\mathrm{V}^{\mathrm{c}}$ & - & $\mathrm{V}$ & $-(1 / 3)$ \\
\hline & & & V & $\mathrm{T}(1 / 3)$ & $\mathrm{V}^{\mathrm{d}}$ & - & $\mathrm{V}$ & $-(6 / 6)$ & & & $\mathrm{V}$ & $\mathrm{T}(2 / 3)$ \\
\hline & $\mathrm{V}^{\mathrm{d}}$ & $\mathrm{T}$ & $\mathrm{V}$ & $\mathrm{T}(4 / 4)$ & $\mathrm{V}^{\mathrm{c}}$ & $\mathrm{T}$ & V & $\mathrm{T}(3 / 3)$ & $\mathrm{V}^{\mathrm{d}}$ & $\mathrm{T}$ & $\mathrm{V}$ & $\mathrm{T}(6 / 6)$ \\
\hline \multirow[t]{2}{*}{ Tn517 } & $-{ }^{\mathrm{d}}$ & - & $\mathrm{V}$ & $-(3 / 3)$ & $-^{\mathrm{c}}$ & $\mathrm{T}$ & - & $\mathrm{T}(3 / 3)$ & $-{ }^{\mathrm{d}}$ & $\mathrm{T}$ & - & $\mathrm{T}(6 / 6)$ \\
\hline & $-^{\mathrm{b}}$ & $\mathrm{T}$ & - & $\mathrm{T}(5 / 5)$ & $-^{\mathrm{b}}$ & - & $\begin{array}{l}- \\
\mathrm{V} \\
\mathrm{V}\end{array}$ & $\begin{array}{l}\mathrm{T}(3 / 9) \\
\mathrm{T}(4 / 9) \\
-(2 / 9)\end{array}$ & $-^{\mathrm{c}}$ & - & $\mathrm{V}$ & $-(3 / 3)$ \\
\hline
\end{tabular}

${ }^{\text {a }}$ Variants selected in $\mathrm{mol}^{1}$ plants were repropagated in two $\mathrm{mol}^{0}$ plants and in three $\mathrm{mol}^{1}$ or $\mathrm{mol}^{2}$ plants. The number of independent plants used as inoculum (depending on how many variants were available following the selection step) and the corresponding sequence of the CI-Cter to VPg region are indicated in the column labeled "Inoculum mol". Mutations observed after sequencing the CI-Cter to VPg region of the progenies are reported in the respective "Progeny" columns. The number of plants for which the sequenced progeny showed a particular haplotype among the total number of plants from which the progeny was characterized are indicated in parentheses. $\mathrm{V}=$ valine, $\mathrm{T}=$ threonine, and - indicates no mutation.

${ }^{\mathrm{b}}$ Three independent plants used as inoculum.

${ }^{c}$ One independent plant used as inoculum.

${ }^{\mathrm{d}}$ Two independent plants used as inoculum.

Table 4. Accumulated nucleotide changes and encoded amino acid (aa) changes in the genome of five mol $^{1}$-adapted Lettuce mosaic virus (LMV) isolates in comparison with their nonadapted parental isolates ${ }^{\mathrm{a}}$

\begin{tabular}{|c|c|c|c|c|c|c|c|c|c|c|c|c|c|c|}
\hline \multirow{2}{*}{$\begin{array}{l}\text { Genomic region } \\
\text { Nucleotide position }\end{array}$} & \multicolumn{5}{|c|}{ P1 } & \multicolumn{5}{|c|}{ CI } & \multicolumn{2}{|c|}{ VPg } & \multirow{2}{*}{$\frac{\text { NIb }}{8685}$} & \multirow{2}{*}{$\begin{array}{c}\text { CP } \\
9496\end{array}$} \\
\hline & 807 & 922 & 937 & 980 & 1048 & 4523 & 5630 & 5883 & 5953 & 5957 & 6610 & 6646 & & \\
\hline Amino acid position & 235 & na & na & 293 & na & 149 & 518 & 602 & na & 627 & na & na & 404 & na \\
\hline Cl427 native & - & - & - & - & - & $\mathrm{G}(\mathrm{A})$ & - & $\mathrm{C}(\mathrm{A})$ & - & - & - & - & - & - \\
\hline $\mathrm{Cl} 427 \mathrm{~mol}^{1}$ adapted & - & - & - & - & - & $\mathrm{T}(\mathrm{S})$ & - & $\mathrm{T}(\mathrm{V})$ & - & - & - & - & - & - \\
\hline $\mathrm{Cl574}$ native & - & - & - & $\mathrm{G}(\mathrm{V})$ & $\mathrm{G}$ & - & - & $\mathrm{C}(\mathrm{A})$ & - & - & - & - & $\mathrm{A}(\mathrm{E})$ & - \\
\hline $\mathrm{Cl} 574 \mathrm{~mol}^{1}$ adapted & - & - & - & $\mathrm{A}(\mathrm{M})$ & A & - & - & $\mathrm{T}(\mathrm{V})$ & - & - & - & - & $G(G)$ & - \\
\hline Tn515 native & - & - & - & - & - & - & - & $\mathrm{C}(\mathrm{A})$ & G & $\mathrm{G}(\mathrm{A})$ & $\mathrm{T}$ & $\mathrm{G}$ & - & $\mathrm{T}$ \\
\hline Tn515 mol ${ }^{1}$ adapted & - & - & - & - & - & - & - & $A(E)$ & $* \mathrm{G} / \mathrm{A}$ & $* \mathrm{G} / \mathrm{A}(\mathrm{A} / \mathrm{T})$ & $\mathrm{C}$ & A & - & $* \mathrm{~T} / \mathrm{C}$ \\
\hline Tn516 native & $\mathrm{A}(\mathrm{K})$ & - & - & - & - & - & - & - & - & $\mathrm{G}(\mathrm{A})$ & - & - & - & - \\
\hline Tn516 mol ${ }^{1}$ adapted & $\mathrm{G}(\mathrm{R})$ & - & - & - & - & - & - & - & - & $\mathrm{A}(\mathrm{T})$ & - & - & - & - \\
\hline Tn517 native & - & A & $\mathrm{C}$ & - & - & - & $\mathrm{G}(\mathrm{G})$ & - & - & $\mathrm{G}(\mathrm{A})$ & - & - & - & - \\
\hline Tn517 mol ${ }^{1}$ adapted & - & $\mathrm{T}$ & $\mathrm{T}$ & - & - & - & $\mathrm{T}(\mathrm{C})$ & - & - & $\mathrm{A}(\mathrm{T})$ & - & - & - & - \\
\hline
\end{tabular}

${ }^{a}$ In the case of coding mutations, the corresponding amino acid is indicated in parentheses. The amino acid positions are numbered according to the genome sequence of LMV-0 (X97704) after maturation of the polyprotein, with the viral protein concerned indicated at the top of the table; - indicates no difference between native and evolved isolates; $*$ indicates both nucleotides are present at the same position in the viral progeny; na $=$ mutations that are silent without inducing any change in the predicted amino-acid sequence. 
The results obtained show that, in addition to the A602V and A627T mutations, none of the other mutations identified by full genome sequencing was observed in the independently evolved virulent variants, indicating that these mutations are not directly associated with the ability to overcome the $\mathrm{mol}^{1}$ resistance and likely reflect genetic drift of the viral lineages sequenced.

\section{Amino acid positions 617 and 621 of the LMV CI-Cter are under positive selection pressure.}

In order to identify amino acids under positive selection pressure in the LMV CI-Cter to VPg region, the nucleotide sequence (nucleotides 5,779 to 6,919) of $81 \mathrm{LMV}$ isolates sampled all over the world and originating from different hosts (T. Candresse, L. Svanella-Dumas, H. Fakhfakh, M. RosalesVillavicencio, R. Krause-Sakate, M. Zerbini, C. Varveri, and O. Le Gall, unpublished data) was analyzed.

As described above, a valine at position 602 and a threonine at position 627 in the CI protein are potentially involved in mol-resistance-breaking by evolved variants of non-lettuce isolates. Previous analysis of multiple sequence alignments between virulent and avirulent LMV isolates had led to the identification of another amino acid of interest at position 621 (Abdul-Razzak et al. 2009). Analysis of the multiple alignments of the $81 \mathrm{LMV}$ sequences revealed that all non-lettuce isolates, regardless of their resistance-breaking status, display a serine rather than the glycine at position 617 observed in the non-resistance-breaking isolates from lettuce (data not shown). Hence, this position appears also as a potential candidate for mol breaking.

Different tools available via the Datamonkey online server were used to try to identify amino acids under positive selection pressure in the LMV CI-Cter to VPg region, as described below. A divergent selection was detected at position 617 with the fast unbiased Bayesian approximation (FUBAR) (probability $=0.82)$ and internal fixed effect likelihood $($ IFEL $)(P$ value $=$ $0.0097)$ models. In both cases, only codon 617 was identified. This is consistent with the observation of seven nonsynonymous mutation events and only two synonymous mutation events at this position in the LMV phylogeny reconstructed using MEGA 5 (Tamura et al. 2011).

The mixed-effect model of episodic selection (MEME) model is a new feature implemented in Datamonkey, aiming to detect episodic divergent selection, acting on a specific subbranch of the phylogenetic tree. This method revealed that codon 621 may have undergone a positive selection $(P$ value $=$ 0.0067). In fact, six nonsynonymous mutation events are observed at this position along the phylogenetic tree, for only three synonymous mutation events. Another position was pre- dicted to be under positive selection by MEME (codon 639 of the CI sequence; $P$ value $=0.0723$ ) but no positive selection signal could be detected for positions 602 and 627 .

Overall, both amino acids 617 and 621 appear to have evolved under divergent selection pressure in the field. While the pressure imposed on 621 appears to have occurred at specific steps during LMV evolution, the selection pressure on position 617 appears to have been active throughout LMV evolution.

\section{Partial resistance breaking triggered by mutations in the CI-Cter.}

The next objective of this study was to establish whether the amino acids at codons 602, 617, 621, and 627 of the CI were molecular signatures or key genetic determinants of the ability to overcome mol-resistance alleles.

Each of the four mutations (A602V, G617S, S621T, and A627T) were introduced alone or in combination in an LMV0 avirulent background (Supplementary Fig. S1). The fulllength cDNA clones obtained were all infectious in susceptible lettuce and their resistance-breaking properties were tested after mechanical inoculation on $\mathrm{mol}^{1}$ and $\mathrm{mol}^{2}$ lettuce plants. Two of the mutants used, LMV-0-A602V and LMV-0S621T, have been previously described (Abdul-Razzak et al. 2009). It is to be noted that, in all cases, symptom appearance on susceptible lettuce occurred as soon as $10 \mathrm{dpi}$, whereas infected resistant lettuce displayed symptoms later, at 20 to 30 dpi. Such a delay in symptom appearance is also observed for some resistance-breaking isolates such as LMV-E (German-Retana et al. 2000). Correlation between symptom appearance and virus accumulation was confirmed by semiquantitative double-antibody sandwich enzyme-linked immunosorbent assay (DAS-ELISA) tests, carried out between 30 and 60 dpi. Regardless of the virus or mutant used and despite calibration of the viral inoculum, LMV accumulation levels in systemic leaves showed high variability in both susceptible and resistant lettuce cultivars, within and between the independent experiments. Hence, no quantitative, meaningful comparisons could be obtained.

It should be stressed that evolution of LMV-0 toward resistance breaking has never been observed over the years. Similarly, in the experiments reported here, no resistance-breakdown was observed when LMV-0 was inoculated to resistant lettuce, even after $60 \mathrm{dpi}$ (Table 5), and the sequence of its CICter region was stable in progenies from susceptible lettuce.

Accumulation of the LMV-0-A627T mutant was detected only once in $\mathrm{mol}^{1}$ and twice in $m o l^{2}$ plants, in only one of the five independent experiments performed (Table 5). Similar to the erratic behavior of the A627T mutant, the double mutants

Table 5. Proportion of susceptible or resistant lettuce plants infected by Lettuce mosaic virus (LMV)-0 or by its mutant derivatives as assessed by doubleantibody sandwich enzyme-linked immunosorbent assay at 60 days postinoculation ${ }^{\mathrm{a}}$

\begin{tabular}{|c|c|c|c|}
\hline LMV mutant (\%) & Susceptible $\mathrm{mol}^{0}(\%)$ & Resistant $\mathrm{mol}^{\mathrm{Ib}}$ & Resistant $\mathrm{mol}^{2 \mathrm{~b}}$ \\
\hline LMV-0 parent & 100 & 0 & 0 \\
\hline LMV-0-A602V & 100 & $0 / 46(0)$ & $0 / 46(0)$ \\
\hline LMV-0-G617S & 100 & $0 / 34(0)$ & $0 / 34(0)$ \\
\hline LMV-0-S621T & 100 & $11 / 36(30.5)$ & $28 / 40(70)$ \\
\hline LMV-0-A627T & 100 & $1 / 17(6)$ & 2/17 (12) \\
\hline LMV-0-A602V-G617S & 100 & $22 / 43(51.2)$ & $30 / 40(75)$ \\
\hline LMV-0-A602V-S621T & 100 & $7 / 27(25.9)$ & $8 / 25(32)$ \\
\hline LMV-0-A602V-A627T & 100 & $3 / 39(7.7)$ & $2 / 41(4.8)$ \\
\hline LMV-0-G617S-S621T & 100 & $7 / 31(22.5)$ & $14 / 33(42)$ \\
\hline LMV-0-G617S-A627T & 100 & $0 / 19(0)$ & $2 / 22(9)$ \\
\hline LMV-0-A602V-G617S-S621T & 100 & $10 / 46(21.7)$ & $38 / 45(84.4)$ \\
\hline LMV-0-G617S-S621T-A627T & 100 & $3 / 4(75)$ & 4/4 (100) \\
\hline
\end{tabular}

\footnotetext{
${ }^{a}$ Values shown correspond to the accumulated data from at least four independent inoculation experiments.

${ }^{\mathrm{b}}$ Percentage of infected plants is given in parentheses.
} 
associating A627T with either A602V or G617S were observed to accumulate in $\mathrm{mol}^{1}$ or $\mathrm{mol}^{2}$ plants in only one of four independent experiments performed and, as a consequence, were not studied further.

Infection of mol-resistant plants by the single mutant LMV0-S621T was reproducibly observed $\left(30.5\right.$ and $70 \%$ of $\mathrm{mol}^{1}$ and $\mathrm{mol}^{2}$ plants infected, respectively), whereas LMV-0A602V and LMV-0-G617S were never observed to accumulate in resistant plants (Table 5). The CI-Cter to VPg region of the viral progenies was sequenced in order to identify potential additional mutations, and was shown to be stable in susceptible and in $\mathrm{mol}^{1}$ plants. In only one progeny from $m o l^{2}$ plants was the threonine at position 621 (ACC) replaced by an isoleucine (ATC) (one of five analyzed progenies) (Table 6).

Consistent with the properties of single mutants, all double or triple mutants carrying the serine-to-threonine mutation at position 621 (S621T) accumulated in $\mathrm{mol}^{l}$ and $\mathrm{mol}^{2}$ plants (Table 5), although, in all cases, the proportion of infected $m o l^{l}$ plants was reproducibly and significantly lower than that of $m o l^{2}$ plants.

The modifications introduced in the CI-Cter region of the double mutant LMV-0-G617S-S621T were stable in susceptible lettuce. In $\mathrm{mol}^{l}$ plants, the A602V (codon GCA into GTA) and A627T (codon GCA replaced by ACA) substitutions independently appeared in one each (variants 1 and 2 , respectively) of the four analyzed progenies (Table 6). In $\mathrm{mol}^{2}$ plants, the introduced serine 617 (AGT) was replaced by an asparagine (AAT) in variants 3 and 5 (observed in 3 and 1, respectively, of the 14 characterized progenies) while the threonine at position 621 (ACC) was replaced by an isoleucine (ATC) in variant 5 (1 of 14 progenies). The A627T substitution was detected in the progenies of variants 3 and 4 (observed in 3 and 1, respectively, of the 14 analyzed progenies).

For the triple LMV-0-G617S-S621T-A627T mutant, the modifications introduced in the $\mathrm{CI}-\mathrm{Cter}$ region were stable in susceptible lettuce. However, in $\mathrm{mol}^{l}$ plants, in one of the three progenies sequenced, an additional mutation at position
100 of the VPg was observed (Table 6, serine AGT to glycine GGT). In $\mathrm{mol}^{2}$ plants, the abovementioned substitution of the introduced serine 617 by an asparagine was detected in variant 2 , which was observed in two of the four characterized progenies (Table 6).

Very interestingly, despite the fact that the corresponding single mutants (LMV-0-A602V or LMV-0G617S) did not accumulate in $\mathrm{mol}^{l}$ and $m o l^{2}$ plants, the double mutant LMV$0-\mathrm{A} 602 \mathrm{~V}-\mathrm{G} 617 \mathrm{~S}$ was observed to accumulate in 51.2 and $75 \%$ of inoculated $\mathrm{mol}^{1}$ and $\mathrm{mol}^{2}$ plants, respectively (Table 5). The triple mutant LMV-0-A602V-G617S-S621T reproducibly and significantly accumulated in more $m o l^{2}$ plants and in fewer ol $^{l}$ plants (Table 5).

In susceptible plants, reversion events occurred at position 602 (the introduced valine reverted to alanine) in the progenies of both the double LMV-0-A602V-G617S (one of nine progenies analyzed) and triple LMV-0-A602V-G617S-S621T mutants (two of eight progenies) after three successive passages on $\mathrm{mol}^{0}$ lettuce (Table 6). In $\mathrm{mol}^{1}$ plants, the A627T substitution appeared in one of the nine analyzed progenies of LMV-0A602V-G617S, in addition to a mutation at position 156 of the VPg (tyrosine to valine). The mutation at position 100 (serine to glycine GGT) of the VPg was also observed in the progenies of LMV-0-A602V-G617S (one of nine analyzed progenies) and LMV-0-A602V-G617S-S621T (one of three progenies). Both $617 \mathrm{~S}$ and $617 \mathrm{~N}$ were also detected in the CI-Cter region of LMV-0-A602V-G617S variant 2 (Table 6). In $\mathrm{mol}^{2}$ plants, the introduced serine 617 was replaced by an asparagine in LMV-0-A602V-G617S variant 3 (representing 2 of the 18 characterized progenies) and LMV-0-A602V-G617S-S621T variants 2 and 3 ( 2 and 1, respectively, of the 11 characterized progenies). Furthermore, the threonine at position 621 was replaced by an isoleucine in the progeny of LMV-0-A602VG617S-S621T variant 3 (1 of 11 progenies analyzed).

Altogether, those results show that the infection of resistant lettuce by the LMV-0-derived mutants is not correlated with the accumulation of additional mutations in the CI-Cter region,

Table 6. Summary of the amino acid changes observed in the cylindrical inclusion (CI) C terminus to genome-linked viral protein genome (VPg) region of Lettuce mosaic virus (LMV)-0 mutants after passaging in susceptible or in resistant lettuce cultivars ${ }^{\mathrm{a}}$

\begin{tabular}{|c|c|c|c|c|c|c|c|c|c|c|c|c|c|}
\hline \multirow[b]{2}{*}{ Codon position } & \multicolumn{4}{|c|}{ Susceptible $m o 1^{0}$} & \multicolumn{5}{|c|}{ Resistant $\mathrm{mol}^{1}$} & \multicolumn{4}{|c|}{ Resistant $\mathrm{mol}^{2}$} \\
\hline & A602 & G617 & S621 & A627 & A602 & G617 & S621 & A627 & VPg S100 & A602 & G617 & S621 & A627 \\
\hline $\begin{array}{l}\text { LMV-0-S621T } \\
\text { Variant (1/5) }\end{array}$ & - & - & $\mathrm{T}$ & - & - & - & $\mathrm{T}$ & - & - & $\begin{array}{l}- \\
-\end{array}$ & $\begin{array}{l}- \\
-\end{array}$ & $\begin{array}{l}\mathrm{T} \\
\mathrm{I}\end{array}$ & $\begin{array}{l}- \\
-\end{array}$ \\
\hline $\begin{array}{l}\text { LMV-0-A602V-G617S } \\
\text { 602-Revertant }(1 / 9) \\
\text { Variant } 1(1 / 9)^{\mathrm{b}} \\
\text { Variant } 2(1 / 9) \\
\text { Variant } 3(2 / 18)\end{array}$ & $\begin{array}{l}\mathrm{V} \\
\mathrm{A}\end{array}$ & $\begin{array}{l}\mathrm{S} \\
\mathrm{S}\end{array}$ & $\begin{array}{l}- \\
-\end{array}$ & $\begin{array}{l}- \\
-\end{array}$ & $\begin{array}{l}\mathrm{V} \\
\mathrm{V} \\
\mathrm{V}\end{array}$ & $\begin{array}{l}\mathrm{S} \\
\mathrm{S} \\
\mathrm{S} / \mathrm{N}\end{array}$ & $\begin{array}{l}- \\
- \\
-\end{array}$ & $\begin{array}{l}- \\
\mathrm{T} \\
-\end{array}$ & $\begin{array}{l}- \\
- \\
\text { G }\end{array}$ & $\mathrm{V}$ & $S$ & - & - \\
\hline $\begin{array}{l}\text { LMV-0-G617S-S621T } \\
\text { Variant } 1(1 / 4) \\
\text { Variant } 2(1 / 4) \\
\text { Variant } 3(3 / 14) \\
\text { Variant } 4(1 / 14) \\
\text { Variant } 5(1 / 14)\end{array}$ & - & $\mathrm{S}$ & $\mathrm{T}$ & - & $\begin{array}{l}- \\
\mathrm{V} \\
-\end{array}$ & $\begin{array}{l}S \\
S \\
S\end{array}$ & $\begin{array}{l}\mathrm{T} \\
\mathrm{T} \\
\mathrm{T}\end{array}$ & $\begin{array}{l}- \\
\overline{\mathrm{T}}\end{array}$ & $\begin{array}{l}- \\
- \\
-\end{array}$ & $\begin{array}{l}- \\
- \\
-\end{array}$ & $\begin{array}{l}N \\
S \\
N\end{array}$ & $\begin{array}{l}\mathrm{T} \\
\mathrm{T} \\
\mathrm{I}\end{array}$ & $\begin{array}{l}\mathrm{T} \\
\mathrm{T} \\
-\end{array}$ \\
\hline $\begin{array}{l}\text { LMV-0-A602V-G617S-S621T } \\
\text { 602-Revertant (2/8) } \\
\text { Variant } 1(1 / 3) \\
\text { Variant } 2(2 / 11) \\
\text { Variant } 3(1 / 11)\end{array}$ & $\begin{array}{l}\mathrm{V} \\
\mathrm{A}\end{array}$ & $\begin{array}{l}S \\
S\end{array}$ & $\begin{array}{l}\mathrm{T} \\
\mathrm{T}\end{array}$ & $\begin{array}{l}- \\
-\end{array}$ & V & $\begin{array}{l}S \\
S\end{array}$ & $\begin{array}{l}\mathrm{T} \\
\mathrm{T}\end{array}$ & - & $\begin{array}{l}- \\
\text { G }\end{array}$ & $\begin{array}{l}\mathrm{V} \\
- \\
\mathrm{V} \\
\mathrm{V}\end{array}$ & $\begin{array}{l}\mathrm{S} \\
- \\
\mathrm{N} \\
\mathrm{N}\end{array}$ & $\begin{array}{l}\mathrm{T} \\
- \\
\mathrm{T} \\
\mathrm{I}\end{array}$ & $\begin{array}{l}- \\
- \\
- \\
-\end{array}$ \\
\hline $\begin{array}{l}\text { LMV-0-G617S-S621T-A627T } \\
\text { Variant } 1(1 / 3) \\
\text { Variant } 2(2 / 4)\end{array}$ & $\mathrm{V}$ & $S$ & $\mathrm{~T}$ & - & $\begin{array}{l}- \\
-\end{array}$ & $\begin{array}{l}S \\
S\end{array}$ & $\begin{array}{l}\mathrm{T} \\
\mathrm{T}\end{array}$ & $\begin{array}{l}\mathrm{T} \\
\mathrm{T}\end{array}$ & $\overline{\mathrm{G}}$ & - & $\begin{array}{l}\mathrm{S} \\
\mathrm{N}\end{array}$ & $\begin{array}{l}\mathrm{T} \\
\mathrm{T}\end{array}$ & $\begin{array}{l}\mathrm{T} \\
\mathrm{T}\end{array}$ \\
\hline
\end{tabular}

${ }^{a}$ Amino acid numbering is according to the genome sequence of LMV-0 (X97704). The position of the amino acids corresponds to the position in the CI protein or in the VPg sequence after maturation of the polyprotein. Mutations in susceptible plants $\left(m o 1^{0}\right)$ were observed after three successive passages while changes in resistant plants $\left(\mathrm{mol}^{l}\right.$ and $\left.\mathrm{mol}^{2}\right)$ occurred during the first passage and were observed at 60 days postinoculation. The number of independent clones acquiring the mutation is indicated in parentheses.

${ }^{\mathrm{b}}$ An additional Y156V mutation is present in the VPg protein sequence. 
because the majority of viral progenies displayed a sequence identical to the inoculated mutant.

\section{Competitiveness of resistance-breaking LMV-0 mutants in susceptible lettuce.}

For viruses and other plant pathogens, gains of virulence on resistant genotypes are frequently associated with fitness loss in susceptible genotypes (Ayme et al. 2007). To investigate the possible fitness cost associated with each mutation, competition tests were performed between the parental LMV-0 isolate and its mutant derivatives. Each mutant was inoculated singly or in mixed infection (1:1 ratio) with its parent, as described below. Viral accumulation (single infections) and the continued presence of the two inoculated viruses (mixed infections) in the systemically infected leaves were monitored at 10, 15, and 20 dpi. The outcome of the competition was the same at 10, 15, and 20 dpi; therefore, the data presented in Figure 2 correspond to the compilation of the results obtained during three independent experiments. In the single-infection assays, no reproducible significant differences of accumulation of the mutant viruses were observed compared with the LMV-0 parent (data not shown).

When LMV-0 and LMV-0-A602V were coinoculated (Fig. $2 \mathrm{~A}$, tests 1,2 , and 3 ), in 38 of the 41 plants, LMV-0-A602V was excluded and LMV-0 was the only virus detected. In only three plants could both viruses still be detected up to 20 dpi by analysis of the electrophoregrams. The presence of both viruses in all the inoculated leaves was verified at $5 \mathrm{dpi}$. This suggests that, in an LMV-0 background, the A602V mutation is associated with a high fitness cost in susceptible lettuce plants.
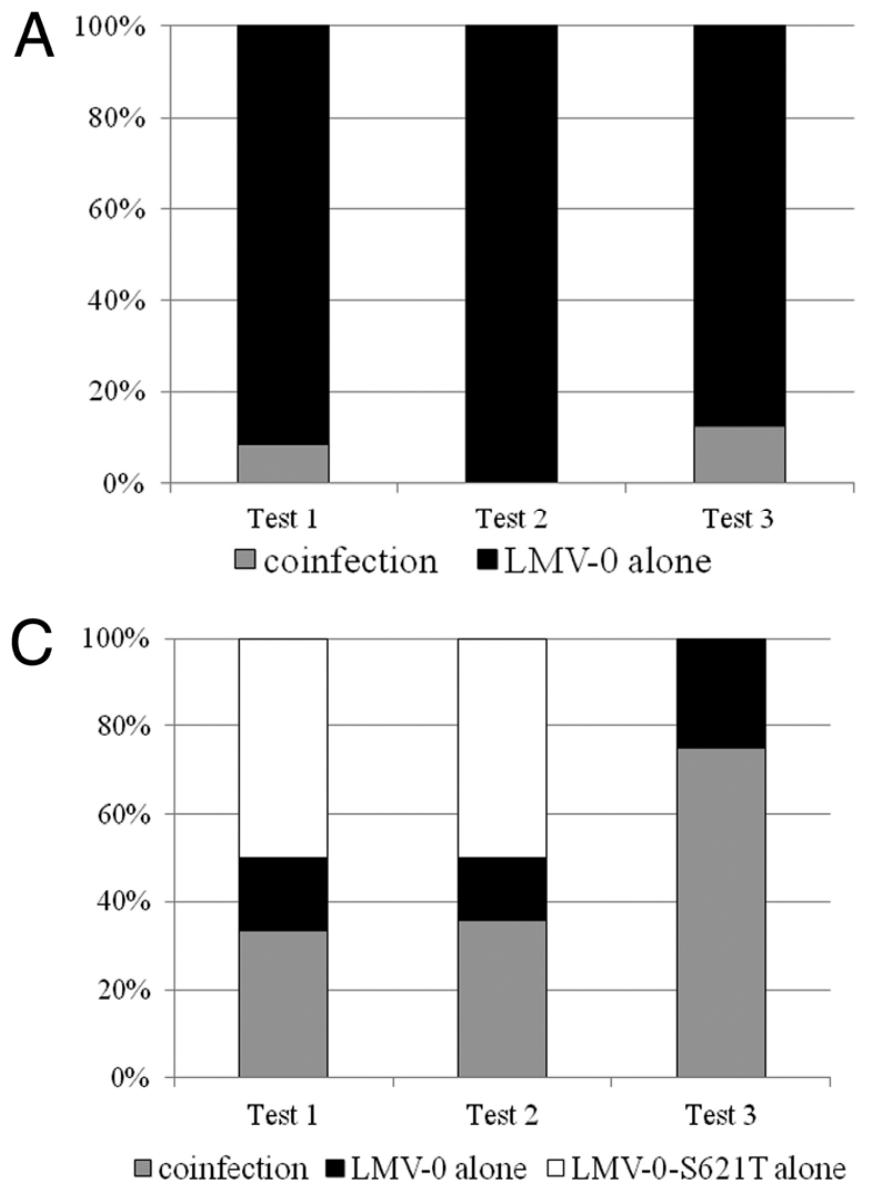

In the case of the G617S mutation, the four independent experiments performed led to variable results (Fig. 2B). However, in all experiments, prolonged co-infection by the two viruses was observed (in a total of 35 of 64 plants), and single infections involving either the parent virus or the G617S mutant were also observed in a number of plants. These results suggest that the G617S mutation does not significantly affect the competitiveness of the mutant compared with LMV-0 in susceptible lettuce.

A similar situation was observed with the S621T mutation (Fig. 2C), because LMV-0 was observed alone in the systemic leaves in only 9 plants out of a total of 48 whereas, in 13 plants, LMV-0-S621T was the only virus detected and, in 26 plants, both viruses were still observed in co-infection. Competition assays performed between LMV-0-G617S and LMV-0A602-G617S resulted in the counterselection of the double mutant (Fig. 2D).

\section{DISCUSSION}

The CI has been shown to be an important determinant of the symptoms caused by potyviruses in productive infections (Chu et al. 1997; Faurez and Baldwin 2012; Krause-Sakate et al. 2005; Redondo et al. 2001). Its C-terminal region has been shown to be involved in the elicitation of defense responses mediated by resistance genes and in interactions with host factors determining recessive resistance in different plantpotyvirus pathosystems (Abdul-Razzak et al. 2009; ChowdaReddy et al. 2011; Fujiwara et al. 2011; Jenner 2002; Jenner et
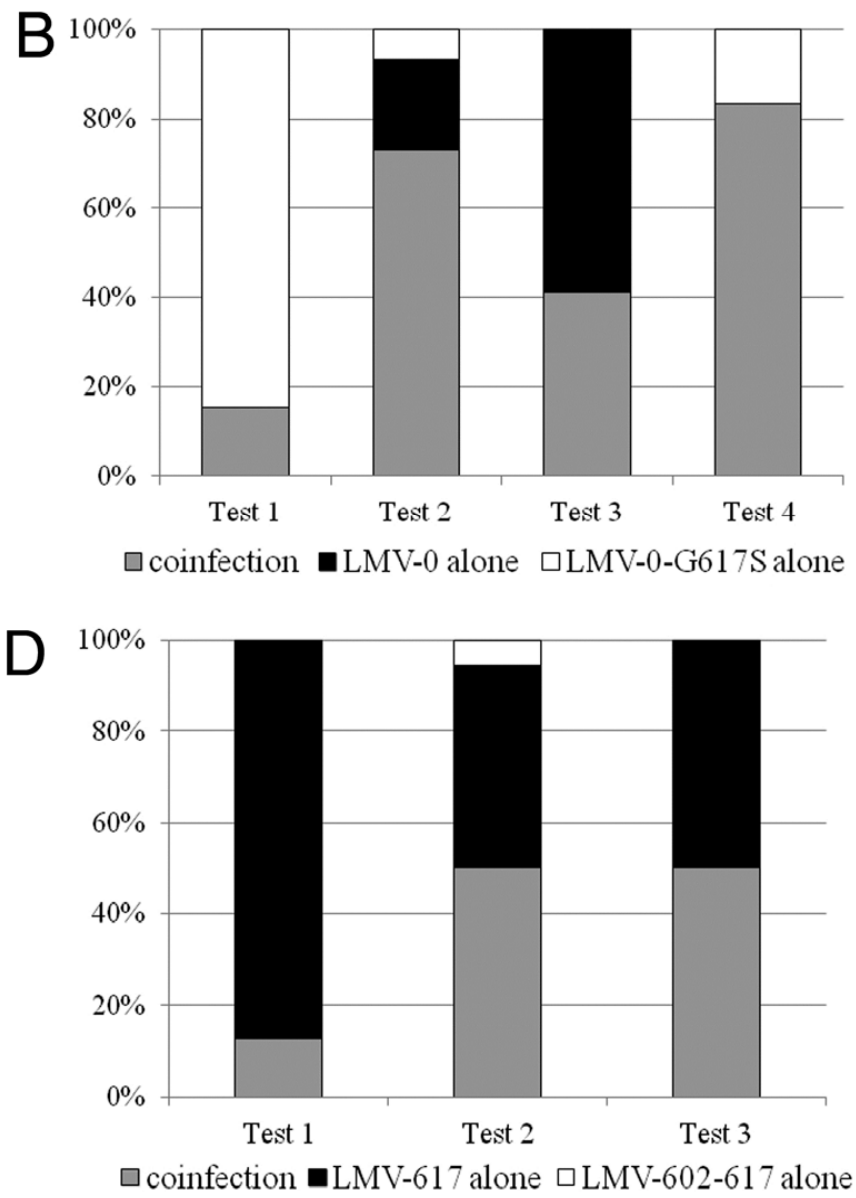

Fig. 2. Outcome of the competitions between coinoculated Lettuce mosaic virus (LMV) isolates in the susceptible lettuce 'Trocadéro'. Graphs show the percentages of plants in which only one of the coinoculated viruses was detected or in which both viral isolates could still be detected at 10 to 20 days postinoculation (dpi). Combinations of competing viral isolates tested were A, LMV-0 versus LMV-0-A602V; B, LMV-0 versus LMV-0-G617S; C, LMV-0 versus LMV-0-S621T; and D, LMV-0-G617S versus LMV-0-A602V-G617S. 
al. 2000). Therefore, the highly variable C-terminal part of the CI protein carries virulence determinants toward numerous plant resistances for different potyviruses (Sorel et al. 2014). Thus, by allowing interaction with variable host factors, CICter variability could potentially be interpreted as a means of adaptation to new hosts.

In this study, we showed that the propagation of five nonlettuce LMV isolates in $m o l^{1}$ and $m o l^{2}$ plants was accompanied by a gain of virulence correlated with the accumulation of mutations at positions 602 or 627 in the CI C-terminal region. This situation was observed in all independently selected virulent variants, whereas those mutations were never selected in susceptible lettuce, in the absence of selection pressure. Whole-genome sequencing of native and evolved isolates showed that no other mutation could be consistently associated with adaptation to the $\mathrm{mol}^{1}$ resistance. Such parallel evolution made both the A602V and A627T substitutions very interesting candidates for $\mathrm{mol}$ virulence determinants. Other amino acid candidates, at positions 617 and 621, were identified through the polymorphism analysis of the CI-Cter to $\mathrm{VPg}$ region of LMV isolates sampled worldwide. The role in mol breaking of each of those four amino acids was studied through reverse genetics experiments performed on the infectious cDNA clone of an avirulent LMV-0 isolate. We have previously shown that the A602V substitution was not sufficient to confer virulence to LMV-0, in contrast to the S621T substitution, which conferred resistance-breaking properties (Abdul-Razzak et al. 2009). The experiments reported here show that the double mutation A602V-G617S is also sufficient to confer virulence to LMV-0, revealing a new mutational pathway and confirming that the $\mathrm{C}$ terminus of the $\mathrm{CI}$ is directly involved in the overcoming of eIF4E-mediated resistance in lettuce.

The CI-Cter to VPg sequence of the large majority of the analyzed progenies of LMV-0 mutants was stable after propagation in susceptible or resistant plants. However, an additional mutation at VPg position 100 or 156 was observed for some progenies of three mutants upon propagation in $\mathrm{mol}^{1}$ and, for some mutants, a proportion of the progenies acquired additional mutations in the CI sequence. In $\mathrm{mol}^{1}$ plants, these additional mutations involved positions 602 or 627 . In $\mathrm{mol}^{2}$ plants, in addition to position 627, additional mutations were observed at the two positions predicted to be under positive selection, 617 and 621 . These results demonstrate the existence of differential mutational pathways depending on the host plant genotype. For each of the LMV-0 resistance-breaking mutants (LMV-0-A602V-G617S, LMV-0-S621T, and LMV-0A602V-G617S-S621T), the rate of infection was significantly lower in $\mathrm{mol}^{1}$ than in $\mathrm{mol}^{2}$ plants. It is tempting to attribute this difference to the mol allele present and to the role played by the VPg in overcoming mol $^{l}$ (Abdul-Razzak et al. 2009) but we cannot exclude an effect of the genetic background of the lettuce varieties used. In this respect, it is noteworthy that LMV non-lettuce isolates were able to evolve toward resistance-breakdown in Salinas 88 plants but not in the early flowering line ' $8714132 \mathrm{M}$ ', although both varieties carry the same $m o 1^{2}$ allele. For another Potyvirus sp., Potato virus $Y$ (PVY), the effect of the host genetic background on the probability of appearance of resistance-breaking mutants and on the speed of fixation of these mutants has been demonstrated (Quenouille et al. 2013).

We also showed that LMV adaptation to mol resistance depends on the viral genetic background. Indeed, in the non-lettuce isolate Tn517, the S617-T627 combination of mutations confers full resistance-breaking properties, in contrast to the situation with LMV-0. Similarly, variants derived from $\mathrm{Cl} 574$ with the V602-S617 combination of mutations infected $100 \%$ of the resistant plants while the corresponding mutations introduced in LMV-0 only allowed accumulation in $51 \%\left(\mathrm{~mol}^{\mathrm{l}}\right)$ to $75 \%\left(\mathrm{~mol}^{2}\right)$ of inoculated plants. Those results are in good agreement with those of Montarry and associates (2011), which showed that the viral genetic background of the CI cistron had a strong impact on the ability of PVY to evolve toward resistance-breaking. The mechanistic basis of this enhanced evolution capacity is unknown but the authors showed that it does not involve an increase in the global mutation rate of the virus.

The evolutionary constraints acting on the two virulence factors of LMV, CI-Cter and VPg, was estimated from 81 sequences deposited in GenBank. The $\omega$ ratio was generally low, indicating that these virulence factors were globally under negative selection and that most amino acid changes were deleterious. However, CI amino acid 617 was found to be under significant positive selection $(\omega>1)$, suggesting a role of this codon in virus adaptation. In the course of all previous assays (AbdulRazzak et al. 2009; German-Retana et al. 2008a; Redondo et al. 2001) and in the present study, the LMV-0 isolate never evolved toward resistance breaking in $\mathrm{mol}^{1}$ or $\mathrm{mol}^{2}$ lettuce, contrary to the non-lettuce isolates analyzed here. LMV-0 differs, in particular, by the presence of a glycine at position 617. Presence of a glycine at this position (G617) is a common feature of lettuce LMV isolates belonging to the Common cluster, N617 is associated with the resistance-breaking Most cluster, and related isolates (Krause-Sakate et al. 2002), while S617 is associated with the rest of LMV clusters, which essentially regroup non-lettuce isolates. This leads to the hypothesis that S617 could be correlated with the "evolvability" of LMV toward virulence against mol resistance, in association with other genetic determinants in the genome, as discussed above. However, the fact that this mutation alone is not sufficient is clearly demonstrated by the observation that the single mutant LMV-0-G617S did not infect resistant lettuce and that no virulent variants emerged in its progeny.

Furthermore, the glycine at position 617 seems to be associated with adaptation of LMV to cultivated lettuce ( $L$. sativa). Indeed, on the basis of the CI-Cter to VPg phylogenetic tree rooted on the LMV Greek cluster, the ancestral codon at position 617 appears to be AGT (serine), suggesting that the acquisition of the GGT codon (glycine) is a posterior event specific to lettuce isolates. In the LMV Common cluster, only two isolates do not have the GGT codon at position 617 but, instead, have AGT, and these are the only isolates from ornamental plants, strengthening the hypothesis that the GGT codon at position 617 could be associated with adaptation to lettuce. From a structural point of view, the replacement at position 617 of a small hydrophobic glycine by a large hydrophilic serine able to establish more hydrogen bonds has the potential to impact the CI-Cter three-dimensional folding. Unfortunately, no crystal structure has yet been obtained for the CI of any potyvirus and modeling is complicated by lack of close homologs of the potyviral CI (Sorel et al. 2014). Analysis of the CICter sequence of LMV-0 with I-TASSER predicted this region to consist of intertwined $\alpha$-helixes, with the G617 and S621 amino acids located in a loop, between two adjacent helices where amino acids A602 and A627 are embedded (data not shown).

In order to understand why the mol resistance has largely remained durable in the field despite the ability to easily select virulent LMV variants in laboratory experiments, we studied the fitness of resistance-breaking LMV mutants. Indeed, the fitness cost associated with mutations involved in virulence has been reported to be important in predicting the resistance durability in several plant-virus pathosystems (Boyd 2006; Lecoq et al. 2004). 
The results reported here clearly demonstrate that mutant LMV-0-A602V has a lower competitiveness than LMV-0. As a consequence, if such a mutation appears in a susceptible lettuce, the resulting virus would be counterselected. These results match the observation of reversion events affecting the A602V mutation in susceptible plants (Table 6). No clear competitiveness cost or improvement seems to be linked to the G617S or S621T mutations. The V602A reversion observed in LMV-0-A602V-G617S and LMV-0-A602V-G617S-S621T progenies after propagation in susceptible lettuce tends to demonstrate that the addition of mutation G617S does not compensate the fitness cost of $\mathrm{A} 602 \mathrm{~V}$ in susceptible lettuce. This is in agreement with the results of competition assays between LMV-0-G617S and LMV-0-A602-G617S (Fig. 2) showing the counterselection of the double mutant.

It has been shown that the nature (transition or transversion) and the fitness cost of mutations are determinant in the capacity of resistance-breaking pathogens to appear and to accumulate (Ayme et al. 2007; Fabre et al. 2009; Janzac et al. 2009). Analysis of the LMV CI-Cter to VPg sequence alignment revealed, as expected, a high transition/transversion ratio $(R=8.98)$ (i.e., 18 times more transitions than transversions). In the present case, the S621T mutation is a transversion which would be expected to have a lower probability to emerge in a viral population.

Given these limitations on the S621T mutation and on the mutational pathway beginning by the $\mathrm{A} 602 \mathrm{~V}$ mutation, the most probable pathway toward virulence seems to be the one starting with the G617S mutation. However, this mutation is absent from the LMV-Common isolates infecting lettuce crops. Given this absence from lettuce isolates and the fact that the LMV-0G617S mutant was, in fact, counterselected in three of the four competition assays against LMV-0, the possibility that this mutation is associated with a fitness cost in susceptible lettuce has to be envisioned. Therefore, the preexistence of the S617 mutation in non-lettuce isolates experimentally shown to be able to infect susceptible lettuce and to evolve toward mol resistance breaking seems to represent the strongest potential threat against mol resistance durability. However, significant correlation between the host of origin and the phylogenetic affinities of LMV isolates within the RoW cluster (T. Candresse, L. Svanella-Dumas, H. Fakhfakh, M. RosalesVillavicencio, R. Krause-Sakate, M. Zerbini, C. Varveri, and O. Le Gall, unpublished data) suggests that host change of LMV between wild or ornamental and cultivated lettuce may be a rather infrequent phenomenon in nature. Although the reasons for this situation are not understood, it would clearly contribute to the mol resistance durability. Overall, the emerging picture is that the durability of the mol lettuce resistance can probably be explained by a combination of factors, including the nature and fitness costs associated with these mutations, but also the circulation of LMV isolates in the environment and the structuring of LMV populations.

\section{MATERIALS AND METHODS}

\section{Plant materials and virus inoculation.}

The non-lettuce isolates of LMV were collected in Chile and in Tunisia from weeds (L. virosa) and ornamental plants ( $\mathrm{Di}$ morphoteca spp.). All isolates were mechanically propagated in the susceptible lettuce (L. sativa) Trocadéro under insect-proof conditions in a greenhouse, following previously described procedures (Revers et al. 1997). Each LMV isolate was also propagated in indicator plants to check for the potential presence of other viruses frequently found in lettuce (Cucumber mosaic virus, Turnip mosaic virus, and Tomato spotted wilt virus).

The infectious recombinant cDNA clones derived from LMV-0 were inoculated by DNA-coated gold particle bom- bardment on susceptible Trocadéro or Salinas lettuce, as previously described (Redondo et al. 2001).

The ability of viral isolates to overcome the mol resistance alleles was evaluated after rub-inoculating at least three plants of cultivars carrying either the $\mathrm{mol}^{1}$ (Mantilia) or the $\mathrm{mol}^{2}$ (Salinas 88 or $8713142 \mathrm{M}$, an early flowering line provided by E. Ryder) alleles. Trocadéro or Salinas were used as susceptible inoculation controls. Salinas and Salinas 88 are near-isogenic lines differing only by their status at the mol locus (Ryder 1991).

\section{Statistical analyses.}

A $\chi^{2}$ statistic test was used to investigate whether LMV-0 mutants differed in their ability to infect resistant lettuce. The $\chi^{2}$ test was used to test the null hypothesis, stating that there is no significant difference between the expected and observed result. By statistical convention, we used the 0.01 probability level as our critical value. If the calculated $\chi^{2}$ value was greater than 0.01 , the hypothesis would be rejected.

\section{Detection and sequencing of viral progenies.}

The appearance of symptoms on the upper-noninoculated leaves was monitored until 14 weeks after inoculation. Symptoms were checked visually and viral infection was confirmed by DAS-ELISA assays (Clark and Adams 1977; GermanRetana et al. 2000). The presence of the virus was confirmed by RT-PCR. Total RNAs were extracted from fresh symptomatic leaves, as previously described (Toth et al. 2002). A coupled one-step RT-PCR was performed using AMV reverse transcriptase (Promega Corp., Madison, WI, U.S.A.) and DyNAzyme II DNA polymerase (Finnzyme, Espoo, Finland) and primer pairs $05762 \mathrm{p}$ and $06419 \mathrm{~m} 2$ (for CI-Cter) or $06197 \mathrm{p} 3$ and $06939 \mathrm{~m}$ (for VPg) (Supplementary Table S2) targeting the viral region involved in mol resistance breaking (CI-Cter to VPg). The amplification products were sequenced on both strands by GATC Biotech (Konstanz, Germany) or Beckman Coulter Genomics (Villepinte, France).

\section{Determination of LMV full-length genomic sequences by Illumina deep sequencing.}

To determine the whole-genome sequence, viral particles of five LMV isolates (C1427, C1574, Tn515, Tn516, and Tn517) before or after their evolution on resistant lettuce were immunocaptured and cDNAs were synthesized and randomly amplified (Svanella-Dumas et al. 2014). One specific 8-bp multiplex identifier tag was used for each sample. The PCR products were purified using the MinElute PCR purification kit (Qiagen, Basel, Switzerland). PCR products (150 ng of each) were pooled and sequenced as a bulk with additional samples using one lane of an Illumina GAIIx flow cell, in the Plateforme Génome Transcriptome of the Centre de Génomique Fonctionnelle de Bordeaux.

All analyses and manipulation of Illumina sequencing reads were performed using CLC Genomics Workbench 5.1. Sequencing reads were first demultiplexed in order to assign individual reads to the relevant sample. The adaptors containing the multiplexing tags were removed from the reads, which were then trimmed on quality. Reads were finally assembled into contigs and scaffolds using a combination of de novo assembly and mapping on an LMV full-length reference genome (LMV-0, X97704). The total number of reads and depth coverage are indicated in Supplementary Table S3.

Gaps in the assembled sequences were filled using PCR on the cDNAs synthesized for the Illumina deep sequencing and specific primers designed from the contig sequences (Supplementary Table S4). The PCR were carried out using $5 \mu \mathrm{l}$ of cDNA in a $50-\mu \mathrm{l}$ reaction volume, $0.2 \mu \mathrm{M}$ each primer, and $1 \mu \mathrm{l}$ 
of 50× Advantage 2 polymerase mix (Clontech, Palo Alto, CA, U.S.A.), according to the manufacturer's recommendations. All amplification products were sequenced by Beckman Coulter Genomics.

\section{Partial targeted sequencing of LMV isolates.}

Partial sequencing of targeted regions of evolved LMV variants genome was performed: cDNAs were synthesized from $5 \mu \mathrm{l}$ of total RNAs using N6 and oligodT18 primers and the Superscript II Reverse Transcriptase (Invitrogen), according to the manufacturer's recommendations. In a second step, the PCR was carried out using the Taq DyNAzyme II DNA polymerase (Finnzyme) and primers.

\section{Construction of point mutants in the CI-Cter region of $\mathrm{LMV-0.}$}

A protocol using homologous recombination in yeast to assemble overlapping DNA fragments and adapted from Desbiez and associates (2012) was used. A cassette containing the $2 \mu$ yeast replication origin and a yeast selectable marker (Trp-1 promoter and gene) was inserted into a plasmid carrying the fulllength infectious cDNA clone of LMV-0 (Abdul-Razzak et al. 2009), yielding the "acceptor" shuttle vector. This vector was further modified by deleting the CI-C-terminal region (nucleotides 5,512 to 6,017 ) and replacing it by a short sequence corresponding to a unique NotI restriction site. The resulting LMV-0DeltaCI vector could then be linearized at this point. PCR-based site-directed mutagenesis was performed using mutagenic primers listed in Supplementary Table S5 to introduce point mutations in the CI-Cter. The CI region (nucleotides 5,416 to 6,117) was amplified from an LMV-0 template through two overlapping mutagenic PCR reactions. When possible, a restriction site was introduced along with the mutation to facilitate the screening of mutated clones. PCR reactions were performed with 0.1 ng of LMV-0 plasmid template, using the Phusion High-Fidelity DNA Polymerase (Finnzyme) according to the manufacturer's recommendations and at a primer annealing temperature (Tm) of $-2^{\circ} \mathrm{C}$ in order to allow for mismatches. The primer Tm were calculated via the Tm calculator tool. The two overlapping PCR fragments were further assembled together with NotI-linearized LMV-0-DeltaCI plasmid by homologous recombination in yeast, as previously described (Desbiez et al. 2012), using competent cells Saccharomyces cerevisiae YPH501 (Sikorski and Hieter 1989).

\section{Estimation of the competitiveness of LMV-0 recombinant mutants.}

Each viral inoculum was calibrated by semiquantitative DAS-ELISA: crude homogenates from infected Trocadéro lettuce plants were calibrated and adjusted by dilution, as reported by Ayme and associates (2006). For competition assays, calibrated inocula were mixed at a 1:1 ratio and used to inoculate 18 susceptible lettuce plants in three independent tests. In parallel, 12 susceptible lettuce plants were inoculated with each individual mutant. Inoculated leaves were harvested at 7 dpi, and the three expanded upper leaves of six plants infected by the two mutants were collected at 10, 15, and $20 \mathrm{dpi}$. Total RNA was extracted, the viral CI-Cter region was amplified by RT-PCR, and the PCR products were directly sequenced. Dual peaks in the sequence electrophoregrams were interpreted as reflecting the coexistence of the two viral genotypes in the viral population. In contrast, a single peak at a polymorphic site between the two competing genotypes suggested that one viral genotype predominated. In parallel, the viral accumulation in plants infected by individual mutants was estimated by DASELISA to quantify viral accumulation in single infections.
Sequence comparisons and phylogenetic analyses.

The nucleotide sequence from nucleotide 5,779 to 6,919 and corresponding to the $\mathrm{C}$ terminus of the $\mathrm{CI}$, the $6 \mathrm{~K} 2$, and the VPg region, for a total of 81 selected LMV isolates (T. Candresse, L. Svanella-Dumas, H. Fakhfakh, M. RosalesVillavicencio, R. Krause-Sakate, M. Zerbini, C. Varveri, and O. Le Gall, unpublished data), was aligned with the ClustalW (Thompson et al. 1997) tool implemented in the MEGA5.0 software (Tamura et al. 2011). A maximum-likelihood tree rooted on LMV isolates from the divergent Greek cluster used as an outgroup (Krause-Sakate et al. 2002) was prepared and used for all further analyses. Mutation events occurring along the tree were inferred using the "infer ancestral sequences" tool of MEGA5. This option uses the maximum-likelihood method to estimate the ancestral state of each node in a phylogenetic tree, for each nucleotide or residue of the alignment.

Detection of sites under diversifying selection was carried out using four different methods: single likelihood ancestor counting, IFEL, FUBAR, and MEME, implemented in the HyPhy package and available on the Datamonkey server (Delport et al. 2010; Murrell et al. 2012, 2013; Pond and Frost 2005a and b; Pond et al. 2006).

The possibility of covariation between sites under diversifying selection pressure and other positions in the CI-VPg region was tested using the Spidermonkey tool (Poon et al. 2008) provided on the Datamonkey server.

\section{ACKNOWLEDGMENTS}

This work was performed with LMV isolates collected in the framework of collaborative programs with Chili and Tunisia coordinated by O. Le Gall and T. Candresse. M. Sorel was supported by a fellowship from the French Ministry of Education. We thank E. Hébrard and B. Moury for fruitful discussions; R. Krause-Sakate, M. Rosales, and H. Fakhfakh for assistance in LMV isolate sampling in Chili and Tunisia; and A. Poque and T. Mauduit for taking care of the plants. M. Sorel, L. Svanella-Dumas, T. Candresse, and S. German-Retana designed, analyzed and interpreted the data. M. Sorel, L. Svanella-Dumas, T. Candresse, and S. German-Retana wrote the article.

\section{LITERATURE CITED}

Abdul-Razzak, A., Guiraud, T., Peypelut, M., Walter, J., Houvenaghel, M.C., Candresse, T., Le Gall, O., and German-Retana, S. 2009. Involvement of the cylindrical inclusion (CI) protein in the overcoming of an eIF4E-mediated resistance against Lettuce mosaic potyvirus. Mol. Plant Pathol. 10:109-113.

Adams, M. J., King, A. M., Lefkowitz, E., and Carstens, E. B. 2011. Part II: The viruses - family Potyviridae. Pages 1069-1090 in: Virus Taxonomy-Ninth Report of the International Committee on Taxonomy of Viruses. Elsevier, Amsterdam.

Ayme, V., Souche, S., Caranta, C., Jacquemond, M., Chadoeuf, J., Palloix, A., and Moury, B. 2006. Different mutations in the genome-linked protein VPg of Potato virus $Y$ confer virulence on the pvr2(3) resistance in pepper. Mol. Plant-Microbe Interact. 19:557-663.

Ayme, V., Petit-Pierre, J., Souche, S., Palloix, A., and Moury, B. 2007. Molecular dissection of the Potato virus $Y$ VPg virulence factor reveals complex adaptations to the pvr2 resistance allelic series in pepper. J. Gen. Virol. 88:1594-1601.

Boyd, L. A. 2006. Can the durability of resistance be predicted? J. Sci. Food Agric. 86:2523-2526.

Chiba, S., Kondo, H., Miyanishi, M., Andika, I. B., Han, C. G., and Tamada, T. 2010. The evolutionary history of beet necrotic yellow vein virus deduced from genetic variation, geographical origin and spread, and the breaking of host resistance. Mol. Plant-Microbe Interact. 24:207-218.

Chowda-Reddy, R. V, Sun, H., Hill, J. H., Poysa, V., and Wang, A. 2011. Simultaneous mutations in multi-viral proteins are required for Soybean mosaic virus to gain virulence on soybean genotypes carrying different $R$ genes. PLoS One 6:e28342. Published online.

Chu, M., Lopez-Moya, J. J., Llave-Correas, C., and Pirone, T. P. 1997. Two separate regions in the genome of the tobacco etch virus contain determinants of the wilting response of tabasco pepper. Mol. PlantMicrobe Interact. 10:472-480. 
Chung, B. Y.-W., Miller, W. A., Atkins, J. F., and Firth, A. E. 2008. An overlapping essential gene in the Potyviridae. Proc. Natl. Acad. Sci. U.S.A. 105:5897-5902.

Clark, M. F., and Adams, A. N. 1977. Characteristics of the microplate method of enzyme-linked immunosorbent assay for the detection of plant viruses. J. Gen. Virol. 34:475-483.

Delport, W., Poon, A. F. Y., Frost, S. D. W., and Kosakovsky Pond, S. L. 2010. Datamonkey 2010: A suite of phylogenetic analysis tools for evolutionary biology. Bioinformatics $26: 2455-2457$

Desbiez, C., Chandeysson, C., Lecoq, H., and Moury, B. 2012. A simple, rapid and efficient way to obtain infectious clones of potyviruses. J. Virol. Methods 183:94-97.

Diaz-Pendon, J. A., Truniger, V., Nieto, C., Garcia-Mas, J., Bendahmane, A., and Aranda, M. A. 2004. Advances in understanding recessive resistance to plant viruses. Mol. Plant Pathol. 5:223-233.

Dinant, S., and Lot, H. 1992. Lettuce mosaic virus. Plant Pathol. 41:528-542.

Elena, S. F., Bedhomme, S., Carrasco, P., Cuevas, J. M., de la Iglesia, F., Lafforgue, G., Lalić, J., Pròsper, A., Tromas, N., and Zwart, M. P. 2011. The evolutionary genetics of emerging plant RNA viruses. Mol. PlantMicrobe Interact. 24:287-293.

Fabre, F., Bruchou, C., Palloix, A., and Moury, B. 2009. Key determinants of resistance durability to plant viruses: Insights from a model linking within- and between-host dynamics. Virus Res. 141:140-149.

Faurez, F., and Baldwin, T. 2012. Identification of new Potato virus $Y$ (PVY) molecular determinants for the induction of vein necrosis in tobacco. Mol. Plant-Microbe Interact. 13:948-959.

Fraser, R. S. S. 1992. The genetics of plant-virus interactions: Implications for plant breeding. Euphytica 63:175-185.

Fujiwara, A., Inukai, T., Kim, B. M., and Masuta, C. 2011. Combinations of a host resistance gene and the CI gene of Turnip mosaic virus differentially regulate symptom expression in Brassica rapa cultivars. Arch. Virol. 156:1575-1581.

German-Retana, S., Candresse, T., Alias, E., Delbos, R. P., and Le Gall, O. 2000. Effects of green fluorescent protein or beta-glucuronidase tagging on the accumulation and pathogenicity of a resistance-breaking Lettuce mosaic virus isolate in susceptible and resistant lettuce cultivars. Mol. Plant-Microbe Interact. 13:316-324.

German-Retana, S., Redondo, E., Tavert-Roudet, G., Le Gall, O., and Candresse, T. 2003. Introduction of a NIa proteinase cleavage site between the reporter gene and HC-Pro only partially restores the biological properties of GUS- or GFP-tagged LMV. Virus Res. 98:151-162.

German-Retana, S., Walter, J., Doublet, B., Roudet-Tavert, G., Nicaise, V., Lecampion, C., Houvenaghel, M.-C., Robaglia, C., Michon, T., and Le Gall, O. 2008a. Mutational analysis of plant cap-binding protein eIF4E reveals key amino acids involved in biochemical functions and potyvirus infection. J. Virol. 82:7601-7612.

German-Retana, S., Walter, J., and Le Gall, O. 2008b. Lettuce mosaic virus : From pathogen diversity to host interactors. Mol. Plant Pathol. 9:127-136.

Janzac, B., Fabre, F., Palloix, A., and Moury, B. 2009. Constraints on evolution of virus avirulence factors predict the durability of corresponding plant resistances. Mol. Plant Pathol. 10:599-610.

Jenner, C. 2002. Mutations in Turnip mosaic virus P3 and cylindrical inclusion proteins are separately required to overcome two Brassica napus resistance genes. Virology 300:50-59.

Jenner, C. E., Sánchez, F., Nettleship, S. B., Foster, G. D., Ponz, F., and Walsh, J. A. 2000. The cylindrical inclusion gene of Turnip mosaic virus encodes a pathogenic determinant to the Brassica resistance gene TuRB01. Mol. Plant-Microbe Interact. 13:1102-1108.

Kang, B.-C., Yeam, I., and Jahn, M. M. 2005. Genetics of plant virus resistance. Annu. Rev. Phytopathol. 43:581-621.

Krause-Sakate, R., Le Gall, O., Fakhfakh, H., Peypelut, M., Marrakchi, M., Varveri, C., Pavan, M. a, Souche, S., Lot, H., Zerbini, F. M., and Candresse, T. 2002. Molecular and biological characterization of Lettuce mosaic virus (LMV) isolates reveals a distinct and widespread type of resistance-breaking isolate: LMV-Most. Phytopathology 92:563-572.

Krause-Sakate, R., Redondo, E., Richard-Forget, F., Jadão, A. S., Houvenaghel, M.-C., German-Retana, S., Pavan, M. A., Candresse, T., Zerbini, F. M., and Le Gall, O. 2005. Molecular mapping of the viral determinants of systemic wilting induced by a Lettuce mosaic virus (LMV) isolate in some lettuce cultivars. Virus Res. 109:175-180.

Lecoq, H., Moury, B., Desbiez, C., Palloix, A., and Pitrat, M. 2004. Durable virus resistance in plants through conventional approaches: A challenge. Virus Res. 100:31-39.

Montarry, J., Doumayrou, J., Simon, V., and Moury, B. 2011. Genetic background matters: A plant-virus gene-for-gene interaction is strongly influenced by genetic contexts. Mol. Plant Pathol. 12:911-920.

Murrell, B., Wertheim, J. O., Moola, S., Weighill, T., Scheffler, K., and Kosakovsky Pond, S. L. 2012. Detecting individual sites subject to epi- sodic diversifying selection. PLoS Genet. 8:e1002764. Published online.

Murrell, B., Moola, S., Mabona, A., Weighill, T., Sheward, D., Kosakovsky Pond, S. L., and Scheffler, K. 2013. FUBAR: A fast, unconstrained Bayesian approximation for inferring selection. Mol. Biol. Evol 30:1196-1205.

Nicaise, V., German-Retana, S., Sanjua, R., Dubrana, M., Mazier, M. Maisonneuve, B., Candresse, T., Caranta, C., and Legall, O. 2003. The eukaryotic translation initiation factor 4E controls lettuce susceptibility to the potyvirus Lettuce mosaic virus. Plant Physiol. 132:1272-1282.

Nicaise, V., Gallois, J.-L., Chafiai, F., Allen, L. M., Schurdi-Levraud, V., Browning, K. S., Candresse, T., Caranta, C., Le Gall, O., and GermanRetana, S. 2007. Coordinated and selective recruitment of eIF4E and eIF4G factors for potyvirus infection in Arabidopsis thaliana. FEBS (Fed. Eur. Biochem. Soc.) Lett. 581:1041-1046.

Pond, S. L. K., and Frost, S. D. W. 2005a. Datamonkey: Rapid detection of selective pressure on individual sites of codon alignments. Bioinformatics $21: 2531-2533$.

Pond, S. L. K., and Frost, S. D. W. 2005b. Not so different after all: A comparison of methods for detecting amino acid sites under selection. Mol. Biol. Evol. 22:1208-1222.

Pond, S. L. K., Frost, S. D. W., Grossman, Z., Gravenor, M. B., Richman, D. D., and Brown, A. J. L. 2006. Adaptation to different human populations by HIV-1 revealed by codon-based analyses. PLoS Comput. Biol. 2:e62. Published online.

Poon, A. F. Y., Lewis, F. I., Frost, S. D. W., and Kosakovsky Pond, S. L. 2008. Spidermonkey: Rapid detection of co-evolving sites using Bayesian graphical models. Bioinformatics 24 :1949-1950.

Quenouille, J., Montarry, J., Palloix, A., and Moury, B. 2013. Farther, slower, stronger: How the plant genetic background protects a major resistance gene from breakdown. Mol. Plant Pathol. 14:109-118.

Redondo, E., Krause-Sakate, R., Yang, S.-J., Lot, H., Le Gall, O., and Candresse, T. 2001. Lettuce mosaic virus pathogenicity determinants in susceptible and tolerant lettuce cultivars map to different regions of the viral genome. Mol. Plant-Microbe Interact. 14:804-810.

Revers, F., Lot, H., Souche, S., Le Gall, O., Candresse, T., and Dunez, J. 1997. Biological and molecular variability of lettuce mosaic virus isolates. Phytopathology 87:397-403.

Ryder, E. J. 1991. "Salinas 88" lettuce. HortScience 26:439-440.

Sikorski, R. S., and Hieter, P. 1989. A system of shuttle vectors and yeast host strains designed for efficient manipulation of DNA in Saccharomyces cerevisiae. Genetics 122:19-27.

Sorel, M., Garcia, J. A., and German-Retana, S. 2014. The Potyviridae cylindrical inclusion helicase: A key multipartner and multifunctional protein. Mol. Plant-Microbe Interact. 27:215-226.

Svanella-Dumas, L., Verdin, E., Faure, C., German-Retana, S., Gognalons, P., Danet, J. L., Marais, A., and Candresse, T. 2014. Adaptation of Lettuce mosaic virus to Catharanthus roseus involves mutations in the central domain of the VPg. Mol. Plant-Microbe Interact. 27:491-497.

Tamura, K., Peterson, D., Peterson, N., Stecher, G., Nei, M., and Kumar, S. 2011. MEGA5: Molecular evolutionary genetics analysis using maximum likelihood, evolutionary distance, and maximum parsimony methods. Mol. Biol. Evol. 28:2731-2739.

Thompson, J. D., Gibson, T. J., Plewniak, F., Jeanmougin, F., and Higgins, D. G. 1997. The CLUSTAL_X Windows interface: flexible strategies for multiple sequence alignment aided by quality analysis tools. $\mathrm{Nu}$ cleic Acids Res. 25 :4876-4882.

Toth, I. K., Hyman, L. J. Bertheau, Y., and Fréchon, D. 2002. DNA amplification by polymerase chain reaction (PCR). Pages 44-65 in: Methods for the Detection and Quantification of Erwinia carotovora subsp. atroseptica (Pectobacterium carotovorum subsp. atrosepticum) on Potatoes: A Laboratory Manual. M .C. M. Perombelon and J. M. van der Wolf, eds. Scottish Crop Research Institute Occasional Publication Number 10. Invergowrie, Scotland.

Wang, A., and Krishnaswamy, S. 2012. Eukaryotic translation initiation factor 4E-mediated recessive resistance to plant viruses and its utility in crop improvement. Mol. Plant Pathol. 13:795-805.

Zerbini, F., Koike, S., and Gilbertson, R. 1995. Biological and molecular characterization of lettuce mosaic potyvirus isolates from the Salinas Valley of California. Phytopathology 85:746-752.

\section{AUTHOR-RECOMMENDED INTERNET RESOURCES}

Centre de Génomique Fonctionnelle de Bordeaux website: www.pgtb.u-bordeaux 2 .fr

CLC Genomics Workbench 5.1 software: www.clcbio.com

Datamonkey server: www.datamonkey.org

I-TASSER software: zhanglab.ccmb.med.umich.edu/I-TASSER

Tm calculator tool: www.neb.com/nebecomm/tech_reference/TmCalc/ Default.asp\#.UKIf02dRqLI 